\title{
Increasing Exports through Tariff Reductions on Intermediate Goods
}

\author{
Nida Jamil ${ }^{*}$ and Rabia Arif ${ }^{* *}$
}

\begin{abstract}
To counter the severe trade deficit problem that Pakistan faces, we explain how to move up the value chain of exports by reducing tariff rates on the intermediate inputs used by local manufacturers. The availability of cheaper intermediate inputs through tariff reductions can substantially reduce input constraints. We begin by identifying trends in the tariff rates imposed on intermediate inputs, and their imports over time by Pakistan and its counterparts. Using an instrumental variable approach, we measure the gains that can be achieved by importing more of these intermediate inputs in terms of export performance indicators. We emphasize that input tariff reductions could help Pakistan expand exports. We also identify specific sectors in which intermediate input tariff reductions could have significant gains for Pakistan in terms of export growth. We recommend the need to reduce intermediate input tariffs in these sectors only, rather than general tariff reductions across all sectors.
\end{abstract}

Keywords: trade deficit, exports, tariffs, Pakistan.

JEL classification: F13.

\section{Introduction}

Over the past decade, Pakistan has substantially reduced its tariffs, especially after entering into free trade agreements (FTAs) with various countries including Sri Lanka, Iran, Mauritius, countries in the European Union and, most importantly, China. While there are numerous channels through which export performance indicators (EPIs) can be improved, such as through better institutions, infrastructure and credit availability, we argue that a potential channel through which Pakistan could benefit is through better use of these FTAs. Specifically, lowering tariffs on the imported intermediate inputs used by domestic exporting firms in production is a potential mechanism for achieving this, in turn helping Pakistan boost its exports in the world market.

\footnotetext{
* Assistant Professor and PhD scholar, Lahore School of Economics, Pakistan.

** Assistant Professor and PhD scholar, Lahore School of Economics, Pakistan.
} 
The gains from reducing tariffs on intermediate inputs are straightforward. Improving the availability and variety of inputs for domestic exporters eases the input constraint, potentially both increasing and improving firms' output for export. It can help firms increase the unit value of existing output being exported (by improving its quality with the availability of better inputs); it also helps exporters climb up the export ladder by manufacturing and ultimately exporting products in which the country is not yet very active. For example, in Pakistan's case, it can compare its export basket relative to India, Sri Lanka, Bangladesh and Turkey and aim to replicate their successes through strategic tariff reductions on intermediate goods.

Reducing tariffs on intermediate inputs can also boost competition among domestic and foreign suppliers. This may induce existing firms to exploit economies of scale if greater competition reduces their market power, forcing them to move down their cost curves and thus produce more (Helpman \& Krugman, 1985). Further, if reduced protection lowers the price of intermediate goods, high-cost domestic suppliers of these inputs will be forced to exit the market, freeing resources for more efficient producers (Rodrik, 1992). Finally, importing cheaper and better-quality inputs, exposure to new products and better methods of production can provide access to better machines and make new technology available to domestic firms, ultimately affecting the productivity of exporting firms.

Much of the emerging literature stresses the importance of intermediate input tariff reductions. Bigsten et al. (2016) study the effect of input and output tariff reductions on firms in Ethiopia. They conclude that exporting firms enjoy large productivity gains from input tariff reductions gains that outweigh the benefits of output tariff reductions. According to Topalova and Khandelwal (2011), reductions in import tariffs are important for developing countries, especially for those emerging from the import substitution phase under which they faced technological constraints because of the nonavailability of imported inputs.

Goldberg et al. (2010) show that lower input tariffs account for around 31 percent of new products being introduced by domestic firms in India, mainly due to the increased access to intermediate inputs that were not available earlier. Cruz and Bussolo (2015) study the impact of trade liberalization, particularly of imposing lower tariffs on intermediate goods, in Morocco. They conclude that firms exposed to greater input tariff reductions perform better in terms of exports, with better access to markets and a higher probability of survival since the imported inputs allow them to 
export new products. This enables them to export higher-value products. The study applies a difference-in-difference methodology, using the FTA between Morocco and other countries as an exogenous shock to the country. Sen (2007) also identifies the importance of reducing prices of capital goods mainly through reductions in tariffs, and highlights the importance of this for India's economic growth.

Contrary to this belief, we may expect a decline in pressure on firms to upgrade due to the reduction in input tariffs. This would result in reluctance to change existing patterns of production, thereby discouraging firms to compete in the product market. A recent study by Bas and Paunov (2018) sheds light on the relevance of complementary factors that may play an important role in determining the effect of tariff reductions on intermediate goods. They argue that the same policy might have a little impact on product growth in the absence of these complementary factors.

This article explores a similar question to Cruz and Bussolo (2015), but using a different methodology to estimate the impact of total imports of intermediate inputs on EPIs via the exogenous decline in intermediate input tariff rates. We use an instrumental variable (IV) approach rather than a difference-in-difference approach, applied to selected countries (Pakistan, Turkey, Sri Lanka, India and Bangladesh).

We begin by looking at trends in intermediate input tariffs for Pakistan, India, Turkey, Sri Lanka and Bangladesh. Specifically, we examine their imports of intermediate inputs over time from the rest of the world. We then focus on how these tariff rates have affected the EPIs for these countries via the import of intermediate inputs. For this, we create a panel dataset using information from the World Integrated Trade Solution (WITS) for 2003-11 for Pakistan, India, Bangladesh, Sri Lanka and Turkey. Among developing countries, these countries were selected specifically for their high export performance in the world market. India and Bangladesh have similar geographical characteristics to Pakistan, while Sri Lanka and Turkey can be taken as significant exporters in the world textiles market.

We use the average intermediate input tariff rate as an instrument for the value of the intermediate input being imported by these countries (in US\$). Next, we look at the direct impact of these imported intermediate inputs on the EPIs. We combine the IV approach with country fixed effects (FE) and time FE to cater for time-invariant unobservables at the country level. We then move from the aggregate level to the sector level, identifying trends in intermediate input tariffs for Pakistan, India, Bangladesh, Sri 
Lanka and Turkey in various sectors. Finally, we look at the direct correlation of intermediate input tariffs with export value at the sector level for all the countries in our sample. We do this to recommend a list of sectors in which Pakistan could gain in terms of boosting exports by lowering the tariffs on intermediate inputs.

We conclude that, over time, all these countries have reduced their tariffs on intermediate inputs, with the most significant reduction by India. As a result, their imports of intermediate inputs from the rest of the world have risen drastically. Moreover, the import of intermediate inputs has had a positive and significant effect on these countries' EPIs, helping them boost their exports. Imported intermediate inputs not only improve export value and volume index, but also improve export unit value. This means that the import of intermediate inputs helps countries export high-quality products, helping them climb up the export ladder.

Finally, high tariffs on intermediate inputs have a negative and significant effect on export value for most sectors in Pakistan. This relationship holds true for all sectors in India and many sectors in Bangladesh. It indicates that reducing tariffs on intermediate inputs would help Pakistan boost its exports. Since a situation exists in India, Pakistan could climb the world export ladder by following in India's footsteps and making those intermediate inputs that are important to the latter available to Pakistani manufacturers.

\section{Stylized Facts}

Given Pakistan's chronic trade deficit (see Figure A1 in the Appendix), it urgently needs to boost its exports. The country's main problem in terms of exports has been its dependence on low value-added agricultural and manufacturing goods. Table 1 compares the top export products for Pakistan and India as in 2016. While low-value products such as textiles, clothing, cotton and fruit remain Pakistan's top exports, India exports high-value products such as gems, stones, vehicles and machinery. 
Table 1: Top ten export products, Pakistan and India, 2016

\begin{tabular}{|c|c|c|c|c|c|}
\hline \multicolumn{3}{|c|}{ Pakistan } & \multicolumn{3}{|c|}{ India } \\
\hline Product & Value & $\begin{array}{l}\text { \% share of } \\
\text { exports in } \\
\text { overall } \\
\text { exports }\end{array}$ & Product & Value & $\begin{array}{c}\text { \% share of } \\
\text { exports in } \\
\text { overall } \\
\text { exports }\end{array}$ \\
\hline $\begin{array}{l}\text { Misc textiles, worn } \\
\text { clothing }\end{array}$ & $\begin{array}{c}\$ 3.8 \\
\text { bn }\end{array}$ & $20.1 \%$ & $\begin{array}{l}\text { Gems, precious } \\
\text { metals }\end{array}$ & $\$ 43$ bn & $16.5 \%$ \\
\hline $\begin{array}{l}\text { Clothing, accessories } \\
\text { (not knitted or } \\
\text { crocheted) }\end{array}$ & $\$ 3$ bn & $16.1 \%$ & $\begin{array}{l}\text { Mineral fuels } \\
\text { including oil }\end{array}$ & $\begin{array}{l}\$ 27.7 \\
\text { bn }\end{array}$ & $10.6 \%$ \\
\hline $\begin{array}{l}\text { Knitted or crocheted } \\
\text { clothing, accessories }\end{array}$ & $\begin{array}{l}\$ 2.6 \\
\text { bn }\end{array}$ & $13.8 \%$ & Vehicles & $\$ 15$ bn & $5.7 \%$ \\
\hline Cotton & $\begin{array}{c}\$ 2.5 \\
\text { bn }\end{array}$ & $13.2 \%$ & $\begin{array}{l}\text { Machinery including } \\
\text { computers }\end{array}$ & $\begin{array}{l}\$ 13.6 \\
\text { bn }\end{array}$ & $5.2 \%$ \\
\hline Cereals & $\begin{array}{c}\$ 916.6 \\
\mathrm{mn}\end{array}$ & $4.9 \%$ & Pharmaceuticals & $\$ 13$ bn & $5 \%$ \\
\hline $\begin{array}{l}\text { Leather/animal gut } \\
\text { articles }\end{array}$ & $\begin{array}{c}\$ 700.6 \\
\mathrm{mn}\end{array}$ & $3.7 \%$ & Organic chemicals & $\begin{array}{c}\$ 11.3 \\
\text { bn }\end{array}$ & $4.3 \%$ \\
\hline $\begin{array}{l}\text { Mineral fuels } \\
\text { including oil }\end{array}$ & $\begin{array}{c}\$ 415.9 \\
\mathrm{mn}\end{array}$ & $2.2 \%$ & $\begin{array}{l}\text { Clothing, accessories } \\
\text { (not knitted or } \\
\text { crocheted) }\end{array}$ & $\$ 9$ bn & $3.5 \%$ \\
\hline Fruits, nuts & $\begin{array}{c}\$ 388.2 \\
\mathrm{mn}\end{array}$ & $2.1 \%$ & $\begin{array}{l}\text { Electrical machinery, } \\
\text { equipment }\end{array}$ & $\begin{array}{c}\$ 8.2 \\
\text { bn }\end{array}$ & $3.1 \%$ \\
\hline $\begin{array}{l}\text { Manmade staple } \\
\text { fibers }\end{array}$ & $\begin{array}{c}\$ 367.3 \\
\mathrm{mn}\end{array}$ & $2 \%$ & $\begin{array}{l}\text { Knitted or crocheted } \\
\text { clothing, accessories }\end{array}$ & $\begin{array}{l}\$ 7.9 \\
\text { bn }\end{array}$ & $3 \%$ \\
\hline $\begin{array}{l}\text { Optical, technical, } \\
\text { medical apparatus }\end{array}$ & $\begin{array}{c}\$ 334.6 \\
\mathrm{mn}\end{array}$ & $1.8 \%$ & Iron, steel & $\begin{array}{c}\$ 6.4 \\
\text { bn }\end{array}$ & $2.5 \%$ \\
\hline
\end{tabular}

Source: http:/ /www.worldstopexports.com/. Retrieved 15 March 2018.

While Pakistan has signed many bilateral agreements in attempts to strengthen its export market, we argue that not much can be achieved through these until and unless Pakistani firms upgrade the products they are exporting and move up the value chain by exporting higher-value products. This is necessary to increase exports. In line with this argument, Goldberg et al. (2013) analyze the relevance of reducing intermediate input tariffs on firms' product mix. They find that the volume of intermediate inputs increases due to a decline in tariff rates on them, and that new high-quality intermediate inputs become available to these firms, thereby expanding their product scope and leading to manufacturing output growth.

The World Bank Enterprise Survey for 2013 gives us a clear picture of the constraints faced by manufacturers in Pakistan. It shows that firms especially in Punjab - that do not export, acknowledge that this is because 
their products cannot compete with those of foreign competitors. This points to a need to eliminate these constraints by intervening in the input market specifically, and enabling Pakistani manufacturers to climb up the export ladder (Figure 1). Reductions in tariffs are a possible form of intervention. Vehicles, for example, are among India's top ten exports (as shown in Table 1), while on the other hand, 80 percent of non-exporting motor vehicle firms in Punjab (Pakistan) report they do not export because they do not believe their products to be internationally competitive.

Figure 1: Obstacles to non-exporting firms in Punjab, frequency by sector

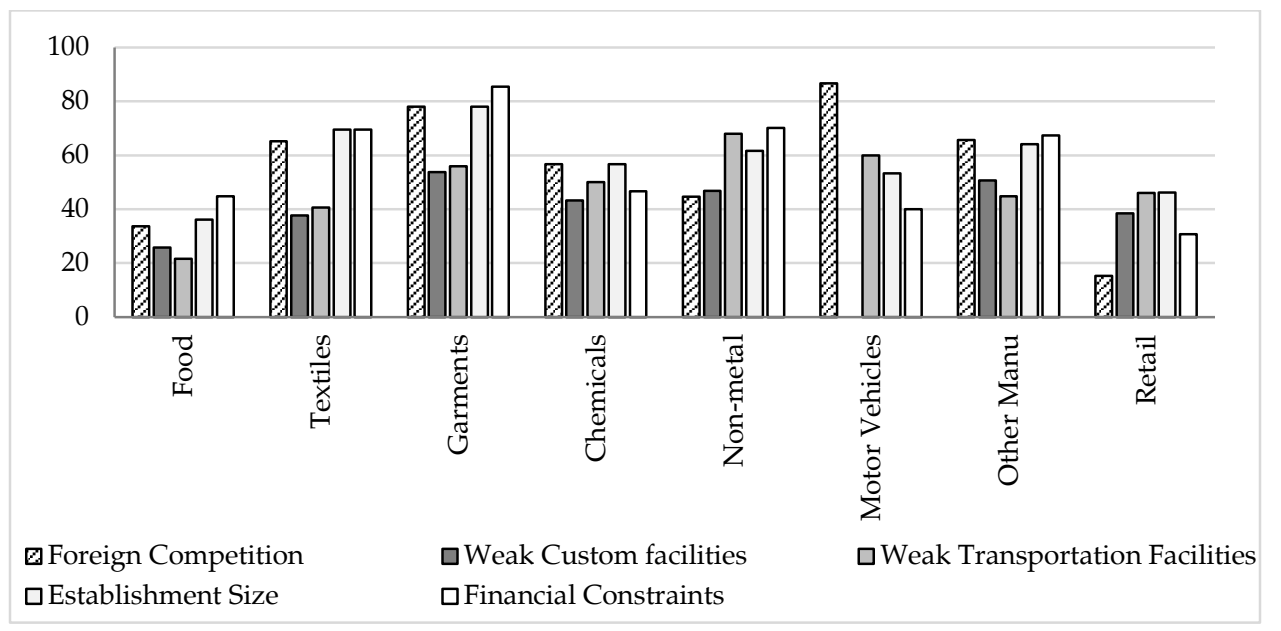

Source: World Bank Enterprise Survey, 2013.

Many firms in Punjab report export market specifications and price competitiveness to be major or severe obstacles (Figure 2). Again, this indicates a need to upgrade the products being exported. More than 40 percent of textile firms and over 60 percent of firms in the garments sector report price competitiveness as a major obstacle. Access to better-quality intermediate inputs through tariff reductions could help resolve both these problems. Better-quality inputs help produce better-quality products, in turn enabling firms to compete internationally and meet export market specifications. The cheap availability of inputs means that firms can charge less for the final good in the world market, enabling them to compete in terms of prices. 
Figure 2: Obstacles (major or severe) to all firms in Punjab

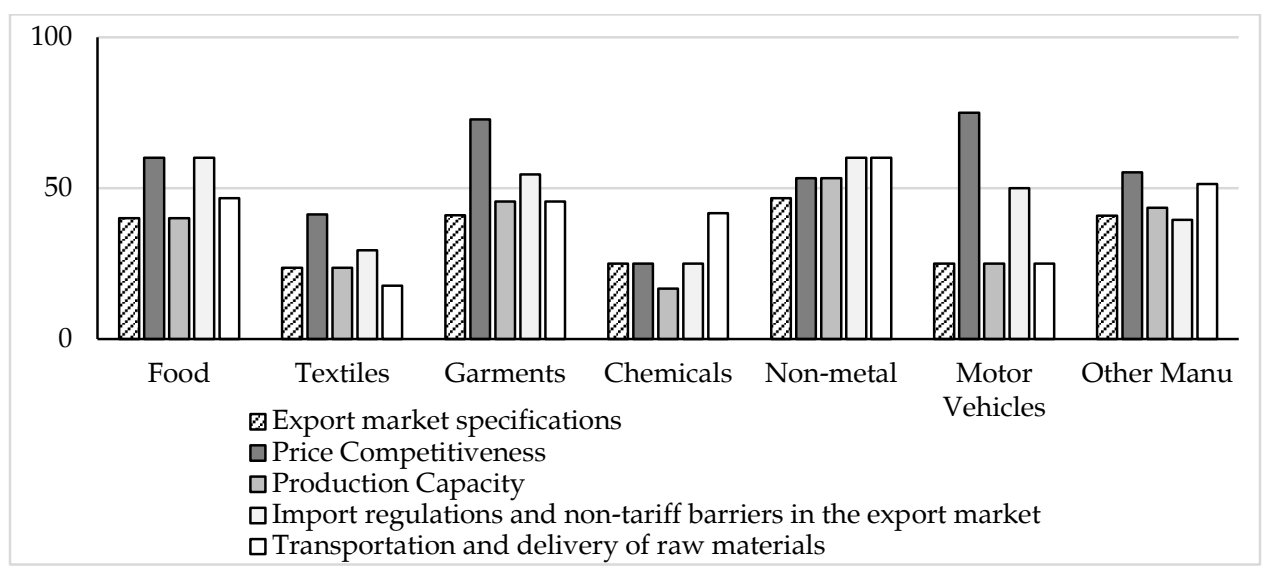

Source: World Bank Enterprise Survey, 2013.

Figure 3 shows that more than 40 percent of firms in all the sectors mentioned below (except retail) report dissatisfaction with the quality of inputs available to them, indicating they need access to better-quality inputs.

Figure 3: Firms in Punjab reporting lower-than-expected quality of intermediate inputs

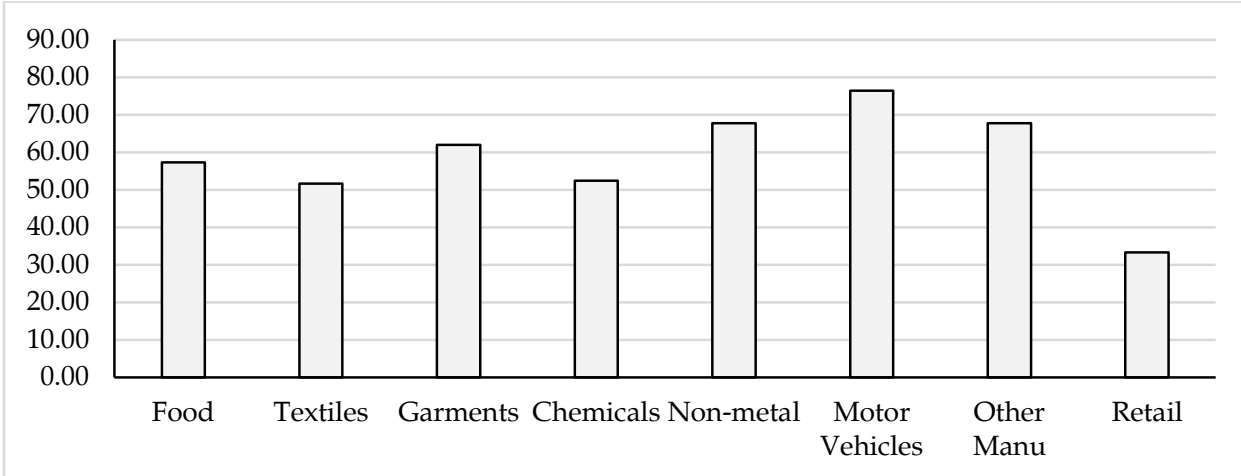

Source: World Bank Enterprise Survey, 2013.

Over time, the world has opened up to trade. Countries including Pakistan, Sri Lanka, India, Turkey and Bangladesh have reduced their average tariff rates on overall imports (see Figure A2 in the Appendix). Figure 4 shows the average tariff rates applied by these countries specifically on imports of intermediate goods. While Pakistan has reduced its tariffs on the import of intermediate goods, what is striking is how considerable India's reduction in tariff rates has been - from more than 25 percent in 2003 to below 10 percent by 2011, which is significantly more than the tariff 
reductions made by Pakistan and Bangladesh. Turkey still applies the lowest tariff rates to intermediate goods. Sri Lanka and Turkey have had a relatively constant tariff rate over this period. A similar situation applies when we look at the average tariff rates applied by these countries to imports of intermediate goods, specifically from China (see Table A3 in the Appendix).

Figure 4: Average tariff rate on intermediate inputs, 2003-11

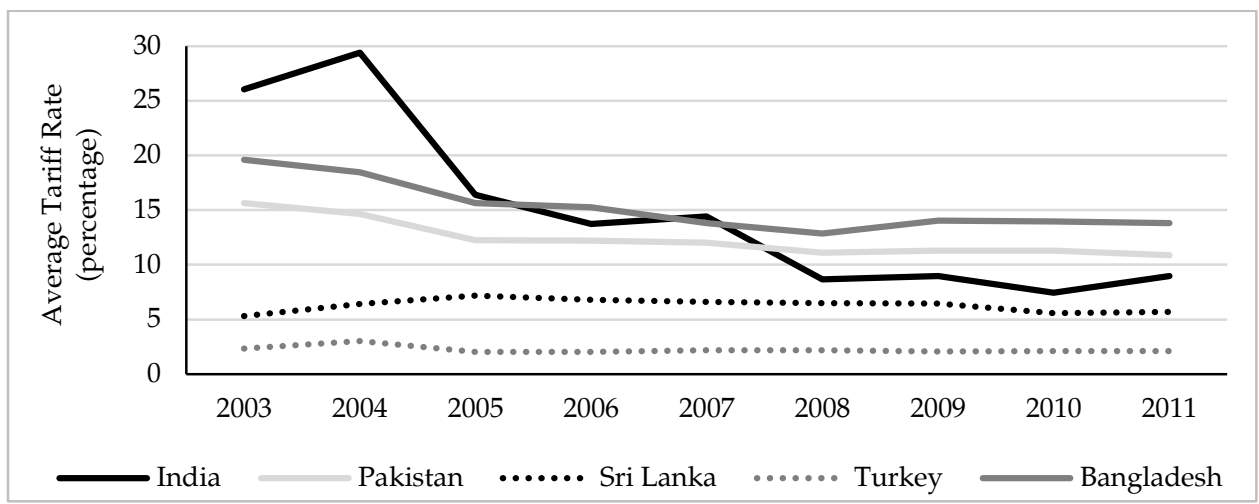

Source: World Integrated Trade Solution.

Due to the large tariff decline, as expected, India's imports of intermediate inputs have grown relative to other countries (Figure 5). Turkey initially had a low tariff rate and has managed to increase its imports of intermediate inputs from the rest of the world. Pakistan's imports have changed only slightly: in 2011, its imports of intermediate goods were even lower than those of Bangladesh. Looking at imports of intermediate goods from China (Figure 6), we see that India is the largest importer of intermediate inputs compared to the other countries in our sample.

Figure 5: Imports of intermediate inputs from the world (US\$), 2003-11

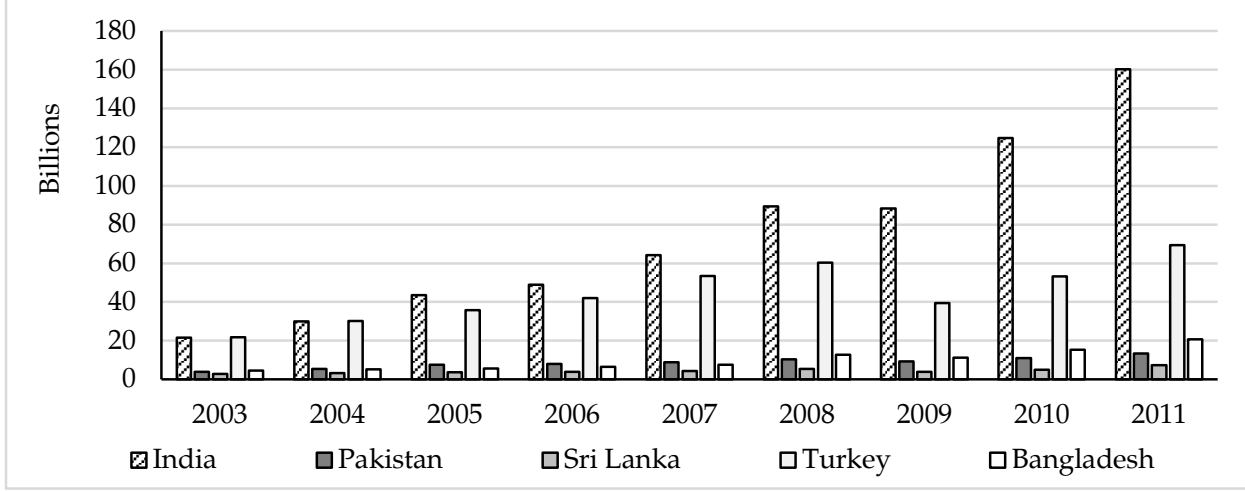

Source: World Integrated Trade Solution. 
Figure 6: Imports of intermediate inputs from China (US\$), 2003-11

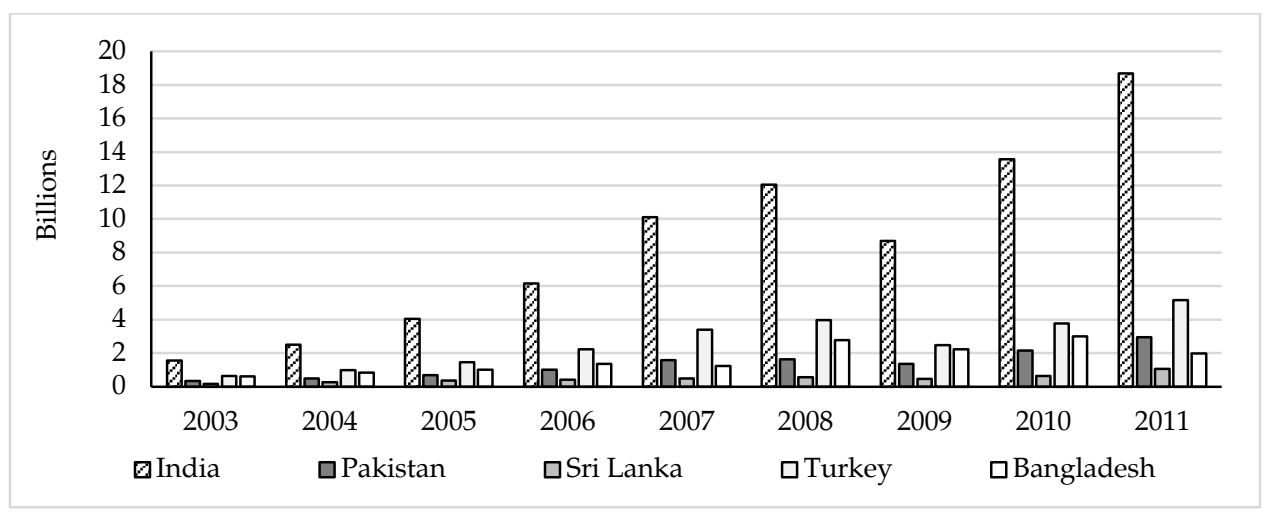

Source: World Integrated Trade Solution.

India's imports of intermediate inputs from China have increased from less than US\$2 billion in 2003 to more than US $\$ 18$ billion. Pakistan's imports have increased over time, but much less than those of India. In 2011, Turkey's imports of intermediate goods from China outperformed Pakistan, rising from less than US\$2 billion in 2003 to around US\$5 billion in 2011.

\section{Theoretical Framework}

We use the theoretical framework proposed by Feng et al. (2016) to explain the channel through which exogenous changes in firm access to imported intermediate inputs affect firm EPIs. The authors argue that firm access to imported intermediate inputs can affect export performance in numerous ways. They use a standard profit maximization function for a firm to evaluate the profits it could earn from international sales as follows:

$$
\operatorname{Max} \pi_{E X}=r(q)-c(q)
$$

where $r$ and $c$ represent firm revenue and costs, respectively, which are a function of the firm's export quantity, $q$.

The following production function, $q=f\left(l, k, m_{d}, m_{f}\right)$, links the output produced by the firm to its input choices, namely, labor $l$, capital $k$, and the availability of local and imported inputs, $m_{d}$ and $m_{f}$. Each intermediate input is selected to maximize the firm's profits by means of its EPIs. Under the binding financial constraints faced by the firm, the relevance of fixed and marginal costs may determine its optimal input mix. Therefore, the costs associated with imported intermediate inputs that are affected 
inversely by cuts in tariff rates can substantially affect the final product $(q)$ the firm produces to export.

The authors propose two main channels through which reductions in tariffs on intermediate inputs can affect the firm's EPIs. First, the quality of imported intermediate inputs available to local manufacturers can enhance the quality of the final product to be exported, making it more competitive in the world export market and directly affecting $r(q)$ in the equation above (see Kugler \& Verhoogen, 2009; Bas \& Strauss-Kahn, 2014; Fan et al., 2015). Second, EPIs can improve through the production function (f) via the production technology affecting firms' total factor productivity (see Ethier, 1982; Kasahara \& Rodrigue, 2008; Amiti \& Konings, 2007; Gopinath \& Neiman, 2014).

\section{Do Tariffs on Intermediate Inputs Affect Export Performance?}

In this section, we focus on the impact of intermediate input tariffs on the import of intermediate goods and eventually on EPIs.

\subsection{Data and Methodology}

The data for this study is taken from the WITS, developed by the World Bank in collaboration with the United Nations Conference on Trade and Development (UNCTAD) and with the help of organizations such as the International Trade Center, the United Nations Statistical Division and the World Trade Organization. We create a panel of five countries - Pakistan, India, Bangladesh, Sri Lanka and Turkey - for the years 2003-11. Taking advantage of this panel dataset, we use country FE along with time FE to account for any time-invariant and across-country unobservable variations.

The following specification is used to estimate the impact of imported intermediate inputs on the EPIs:

$$
\begin{aligned}
E P_{c t}= & \beta_{0 c t}+\beta_{1} \log (\text { intermediate input US\$ })_{c t}+\text { country }_{c}+ \\
& \text { year } r_{t}+u_{c t}
\end{aligned}
$$

where $E P_{c t}$ refers to the seven ways of measuring export performance as listed below, which vary with country and time. Intermediate input (measured in US\$) is the total value of imported intermediate inputs from the rest of the world for each country over time. Country $y_{c}$ refers to country $\mathrm{FE}$ and $y e a r_{t}$ to time FE, while $u_{c t}$ is the time-varying error term.

We take various measures of a country's EPIs: 
- Exports (US\$ '000): The net value of a country's exports.

- Export volume index: This is derived from UNCTAD's volume index series and is the ratio of the export value index to the corresponding unit value index. The year 2000 is taken as the base year. ${ }^{1}$

- Export value index: The current value of exports converted to US dollars and expressed as a percentage of the average for the base period (2000).

- Export unit value index: The ratio of the export value index to the export volume index. ${ }^{2}$

- Index of export market penetration: This measures the extent to which a country's exports reach already proven markets. It is calculated as the number of countries to which the reporter exports a given product divided by the number of countries that report importing the product that year. ${ }^{3}$

- Number of export products: The number of partner markets for a country. A market is counted if the exporter ships at least one product to that destination in the given year with a trade value of at least US $\$ 10,000$.

- Herfindahl-Hirschman market concentration index: A measure of the dispersion of trade value across an exporter's partners. A country whose trade value is concentrated in very few markets will have an index value close to 1 . Thus, it is an indicator of the exporter's dependency on its trading partners and the risk it faces should its partners increase trade barriers. Measured over time, a fall in the index may be an indication of diversification in the exporter's trading partnerships.

Equation (1) suffers from a potential problem of endogeneity and may estimate biased coefficients for the impact of imported intermediate inputs on EPIs. Even if we control for country FE and year FE, there are still types of variation that are unobserved at the product level which may affect the dependent variable (the EPI) and independent variable (the imported intermediate input) simultaneously. For example, a country may experience a demand shock (unobserved) that could affect its EPIs as well as its imports

\footnotetext{
${ }^{1}$ In the year 2000, the index equals 100 .

${ }^{2}$ Since both the numerator and denominator were normalized by the base year 2000, the export unit value index is not normalized by the base year.

${ }^{3}$ A low export penetration may signal the presence of barriers to trade that are preventing firms from expanding the number of markets to which they export.
} 
of intermediate inputs needed to manufacture those products, thereby resulting in biased estimates.

To address the endogeneity problem as discussed above, we use an IV estimation approach. The IV should fulfill two criteria: it should be highly correlated with the intermediate input value and fulfill the exclusion restriction, that is, it should be uncorrelated with the EPIs through any channel other than changes in the intermediate input value. Therefore, we use average intermediate input tariff rates as an instrument for the total import of intermediate goods (US\$) for each country for each year, as used by Goldberg et al. (2010). We argue that the instrument is valid and fulfills the exclusion restriction. Since a reduction in the tariff rates for intermediate inputs would directly affect their prices, making them available to local manufacturer at a cheaper rate, this would eventually improve the EPI via this channel alone.

The first-stage equation is as follows:

$$
\begin{aligned}
& \log (\text { intermediate input } U S \$)_{c t}=\alpha_{0 c t}+ \\
& \quad \alpha_{1} \text { average tariff rate on the intermediate input } t_{c t}+\xi_{c t}
\end{aligned}
$$

Estimates from the first stage are then used in the second stage where $E P_{c t}$ refers to the seven ways of measuring export performance, which vary with country and time. $C_{c}$ refers to country FE while $u_{c t}$ is the time-varying error term.

$$
E P_{c t}=\beta_{0 c t}+\beta_{1} \log (\text { intermed } \widehat{\text { late }} \text { input US } \$)_{c t}+c_{c}+u_{c t}
$$

\subsection{Descriptive Statistics}

Table 2 gives the mean values of the dependent and independent variables used in the empirical estimations for each country in our sample. 


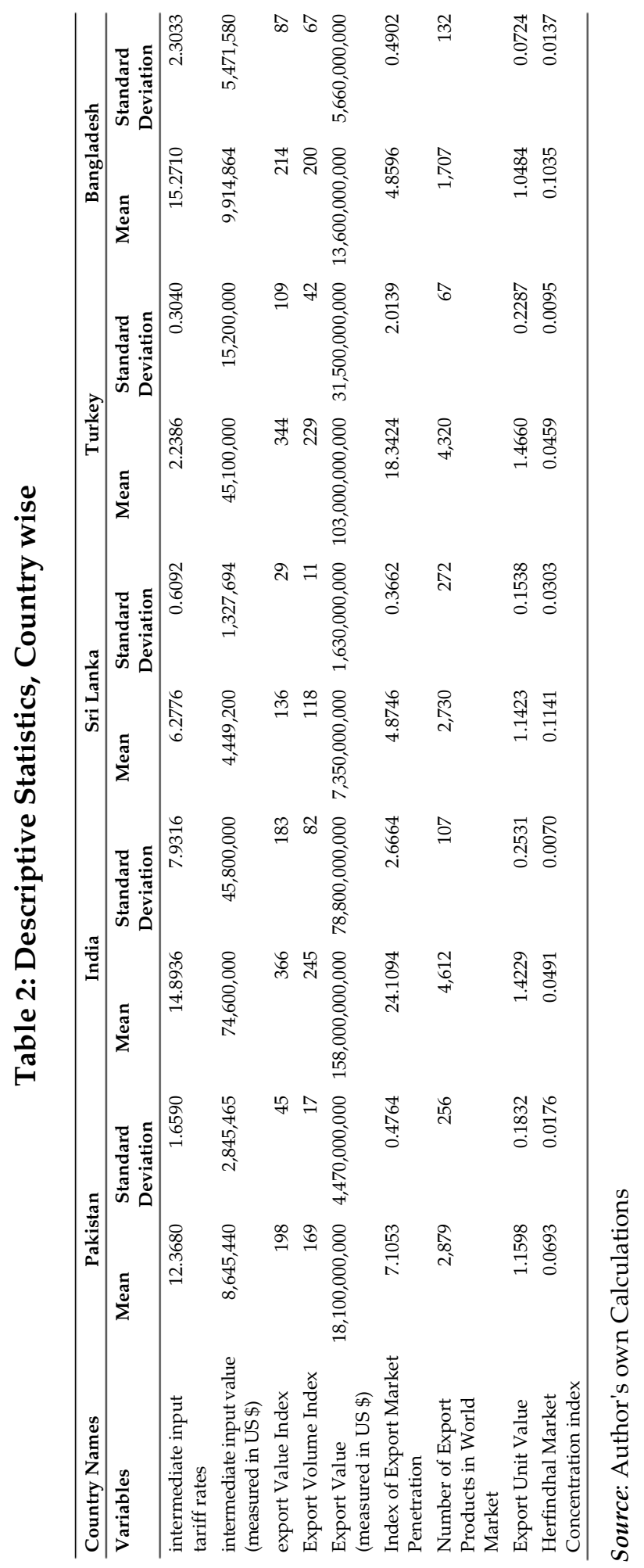




\subsection{Results}

Our results are shown in Table 3. The first-stage results (Table 3A) show that the coefficient of intermediate inputs is significant and negative, indicating that a rise in the tariff on imported intermediate inputs leads to a decline in their import. The second-stage results (Table 3B) indicate that the import of intermediate goods has a significant impact on all export measures except for the export unit value and the number of export products. We give the OLS results side by side for a base comparison. For almost all EPIs, we can see that the OLS results are overstated. ${ }^{4}$ The direction of bias is consistently positive across all the specifications, which is in line with the magnitude of bias we expect due to omitted variables such as demand shocks. If, on one hand, positive demand shocks affect the EPIs positively, they will also increase the value of intermediate inputs simultaneously, causing an upward bias.

Table 3A: Impact of intermediate input tariffs through import of intermediate inputs on export performance indicators

\begin{tabular}{lc}
\hline & Log (intermediate input) \\
\hline Average tariff rate of intermediate goods & $-0.0404^{* * *}$ \\
& $(0.0069)$ \\
Year fixed effects & Yes \\
Country fixed effects & Yes \\
F-value of the excluded instruments & 321.35 \\
\hline
\end{tabular}

\footnotetext{
${ }^{4}$ For all the EPIs except for the number of export partners, the OLS results are biased upward.
} 


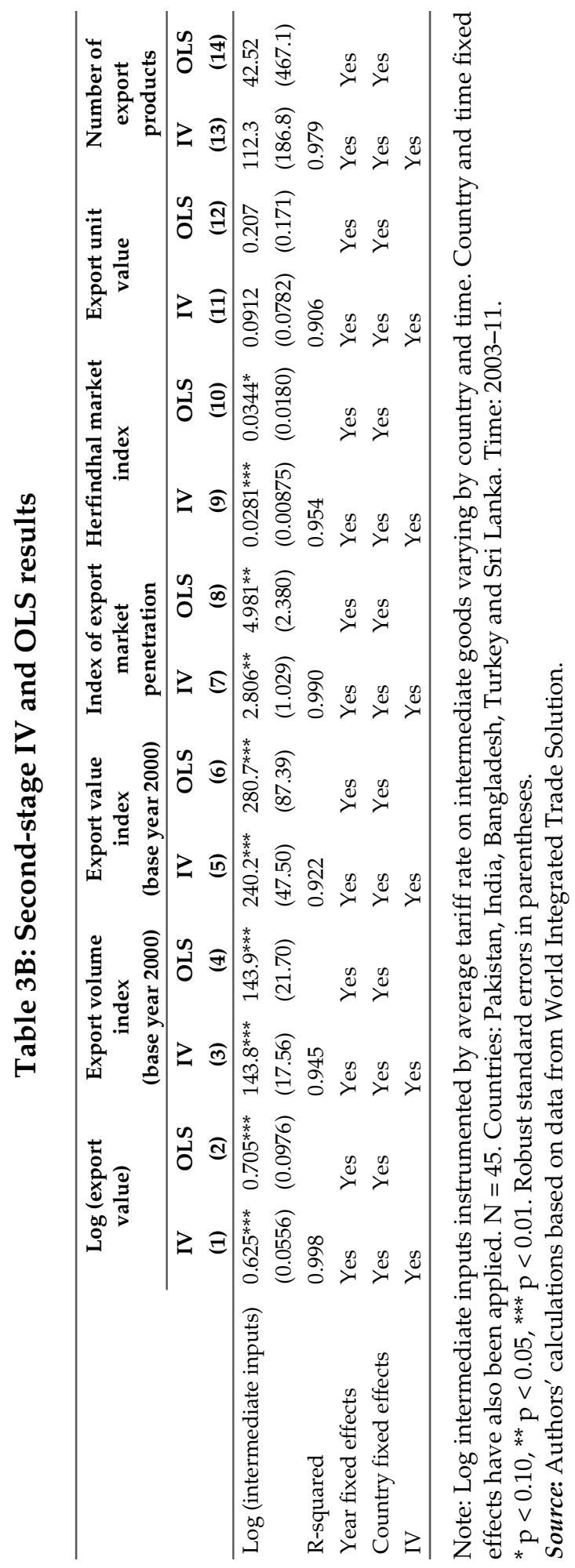


We interpret the IV results below since they are econometrically stronger. The main results are:

- An increase in import of intermediate inputs leads to an increase in the value of exports (in US\$). On average a one percent increase in the import of intermediate goods increases the value of exports by 0.625 percent.

- An increase in the import of intermediate inputs leads to an increase in the export volume index. On average if the import of intermediate inputs increases by 1 percent, the export volume index goes up by 1.43.

- An increase in the import of intermediate inputs leads to an increase in the export value index. On average, if the import of intermediate inputs increases by 1 percent, the export value index increases up by 2.4 .

- An increase in the import of intermediate inputs increases export market penetration.

- An increase in the import of intermediate inputs increases the HF index. This implies that the import of intermediate goods decreases the number of markets that a country is exporting to.

The results also imply that higher imports of intermediate inputs lead to higher value added exports (represented by the export unit value index) and an increase in the number of traded products, though these results are not significant.

These findings are in line with the theoretical framework in Section 3 , where we have argued that a reduction in tariffs on intermediate inputs would have a significant and positive effect on EPIs. However, our findings contradict Bas and Paunov (2018), who argue that access to new inputs through input trade liberalization has little impact on product growth since other complementary factors such as skilled labor and institutions are also important. Our results show that the impact of input tariff reductions is large and significant even if the variable does not interact with the quality of institutions and labor. The FE ensures that these important variables are not causing any bias in our estimations. Therefore, reducing the cost of inputs does not eliminate the pressure on firms to be more competitive, hence discouraging them from upgrading their EPIs. 


\section{Intermediate Input Tariffs and Correlation with Export Value}

Here, we carry out a sector-level analysis by estimating the trends in intermediate input tariffs at the sector level for Pakistan, India, Sri Lanka, Turkey and Bangladesh. We then look at the direct impact of intermediate input tariffs on export value for Pakistan and its comparable counterparts for various sectors. We identify important sectors for Pakistan, where, if the intermediate tariffs are reduced, exports will grow.

\subsection{Data and Methodology}

We begin by listing the inputs used by firms in different sectors, using the Census of Manufacturing Industries (CMI) for Punjab 2005/06. The CMI identifies the quantities and values of inputs used by firms, distinguishing between domestic and imported inputs. These inputs are based on ISIC 3.1. We convert these inputs into comparable HS codes, identifying the possible inputs used by different sectors. Next, we identify the tariff rates applicable by different countries (Pakistan, India, Bangladesh, Turkey and Sri Lanka) on these inputs, again based on the HS codes for 2000, 2007 and 2014. This data is obtained from the WTO's Tariff Analysis Online. Finally, we obtain the value of sector-level exports for each of these countries over the three years from the WITS.

\subsection{Results}

Table 4 lists the sector-wise average intermediate input tariff rates for Pakistan, India, Turkey, Sri Lanka and Bangladesh for different years. 


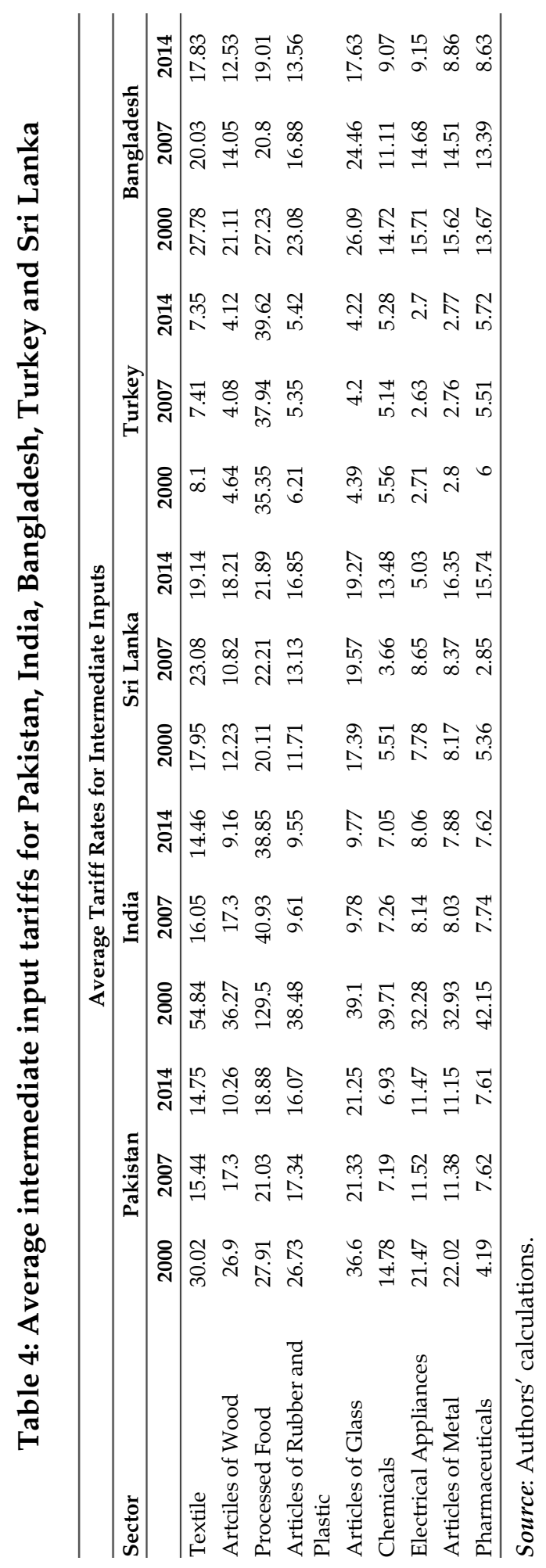


This is in line with Figure 4, which shows the trends in intermediate input tariffs for these countries. Among all these countries in 2000, India starts with the highest tariff rates and shows a gradual decline, reaching comparable rates with those of other countries in 2014. Pakistan and Bangladesh have also reduced their input tariffs, while Sri Lanka has increased its average tariff slightly for most of these sectors. An interesting observation for Sri Lanka, in terms of the tariffs for individual inputs, is that its tariff rates are 0 for all those inputs in which it does not have a comparative advantage, and are high for products in which it does have a comparative advantage. 5 The tariff rates for Turkey remain more or less the same on average, with a slight difference between these 14 years.

Next, we look at the direct relationship of these intermediate input tariffs with the export values for these countries at the sector level in Table 5. The coefficients estimated in the table are obtained through OLS. Although we may not infer causation from these coefficients, they still give us some insight into how heavily the intermediate input tariffs affect export value at the sector level.

Table 5: Impact of intermediate input tariffs on export value, by sector

\begin{tabular}{lccccc}
\hline Sector & Pakistan & India & Sri Lanka & Turkey & Bangladesh \\
\hline Textile & $-0.0173^{* * *}$ & $-0.0056^{* * *}$ & -0.000 & -0.0049 & $-0.0612^{* * *}$ \\
& $(0.0028)$ & $(0.0020)$ & $(0.0050)$ & $(0.0137)$ & $(0.0119)$ \\
Articles of wood & $-0.0898^{*}$ & $-0.0457^{* *}$ & 0.1141 & -0.1733 & $-0.0925^{*}$ \\
& $(0.0345)$ & $(0.0101)$ & 0.0528 & $(0.5998)$ & $(0.0419)$ \\
Processed food & -0.0113 & $-0.0107^{* * *}$ & 0.0032 & -0.0045 & $-0.0597^{* * *}$ \\
& $(0.00690)$ & $(0.0013)$ & $(0.0198)$ & $(0.0039)$ & $(0.0213)$ \\
Articles of rubber & $-0.0598^{* * *}$ & $-0.0423^{* * *}$ & $0.1468^{* *}$ & -0.0858 & $-0.2212^{* * *}$ \\
and plastic & & & & & \\
& $(0.0187)$ & $(0.0092)$ & $(0.0446)$ & $(0.2095)$ & $(0.0229)$ \\
Articles of glass & $-0.0598^{* * *}$ & $-0.0423^{* * *}$ & $0.1468^{* *}$ & -0.0858 & $-0.2212^{* * *}$ \\
& $(0.0187)$ & $(0.0092)$ & $(0.0446)$ & $(0.2095)$ & $(0.0229)$ \\
Chemicals & $-0.0366^{* * *}$ & $-0.0368^{* * *}$ & $0.0637^{* *}$ & 0.0060 & -0.0034 \\
Electrical appliances & $(0.0128)$ & $(0.0064)$ & $(0.0346)$ & $(0.0677)$ & $(0.0207)$ \\
& $-0.0498^{* * *}$ & $-0.0488^{* * *}$ & 0.0452 & 0.0204 & -0.0283 \\
Articles of metal & $(0.0146)$ & $(0.0079)$ & $(0.0249)$ & $(0.2145)$ & $(0.0351)$ \\
& $-0.0571^{* * *}$ & $-0.0445^{* * *}$ & -0.0047 & -0.0014 & $-0.0510^{* *}$ \\
Pharmaceuticals & $(0.0136)$ & $(0.0029)$ & $(0.0091)$ & $(0.0715)$ & $(0.0234)$ \\
& -0.0558 & $-0.0390^{* * *}$ & 0.0238 & -0.0036 & 0.0022 \\
& $(0.0306)$ & $(0.0105)$ & $(0.0269)$ & $(0.0993)$ & $(0.1104)$ \\
\hline
\end{tabular}

Source: Authors' calculations.

${ }^{5}$ This means that Sri Lanka is importing inputs that are of better quality in the world market while protecting those inputs it can produce itself. 
Among the sampled countries, exports for all these sectors are significantly affected by input tariffs in all sectors for India. The negative sign shows that a higher input tariff in these sectors leads to a decline in that export. Pakistan shows a similar result, where a high tariff on inputs in most sectors has a negative impact on the export value. In Pakistan, textiles, wood, rubber and plastic, glass, chemicals, electrical appliances and metal are significantly affected by intermediate input tariffs.

This negative relationship can be seen for most sectors in Bangladesh as well. For Turkey, intermediate input tariffs affect exports negatively for most sectors, but are not significant. The case of Sri Lanka is different: higher tariffs help boost exports in rubber and plastic, glass and chemicals, but are not significant for the other sectors.

\section{Conclusion and Recommendations}

There is a significant need for Pakistan to boost its exports and climb up the export ladder, given its worsening trade deficit. While there are numerous channels - institutions, better infrastructure, credit constraints etc. - through which export performance can be improved, we argue that one potential channel is a reduction in intermediate input tariff rates. Lowering tariffs on these intermediate inputs could help local manufacturers in two ways: first, by providing cheaper intermediate inputs and, second, by making new, better-quality intermediate inputs available to Pakistani exporters.

We show that there are substantial gains for countries in terms of better export performance by lowering the tariffs on imported intermediate inputs. Using an IV approach, we measure the impact of the value of intermediate inputs used by Pakistan, India, Turkey, Sri Lanka and Bangladesh for the years 2003-11 on various EPIs. With the intermediate input tariffs applied by these countries as the instrument, we find that imported intermediate inputs have a positive and significant effect on all EPIs except for the number of trading partners.

Having established that there are gains to be had from intermediate input tariff reductions, we narrow down our analysis by identifying which sectors may experience the most significant gains due to lower intermediate input tariffs. We do this by looking at the direct relationship between the export value and average intermediate inputs. For Pakistan, textiles, wood, rubber and plastic, glass, chemicals, electrical appliances and metal could be 
significantly affected by intermediate input tariff reductions. This pattern is similar to that of India.

The counter-argument is that reductions in tariff rates may discourage local manufacturers of these intermediate inputs due to greater competition overseas. Therefore, we recommend that the government focus on reducing intermediate input tariffs in those sectors identified above. We propose a careful analysis of intermediate inputs and tariff reductions even within these sectors and suggest taking a more strategic approach to reducing tariffs on a selected range of intermediate inputs, as identified by Arif and Jamil (2018), in the case of the textiles sector. The tariff reductions were proposed based on a careful assessment of the quality of intermediate inputs produced locally relative to the international market in that sector. We recommend importing only high-quality intermediate inputs that are not produced in the domestic market. ${ }^{6}$ This strategic reduction in tariffs will not only benefit local manufacturers of the final good by providing them with high-quality intermediate inputs, but it will also protect local input manufacturers along with minimizing the revenue loss for the government due to this policy.

Climbing the export ladder means making these inputs available to Pakistani manufacturers. After identifying these inputs, the government could further narrow down the list of intermediate inputs for which tariffs should be lowered by comparing the unit value of the imported intermediate inputs with that already available to Pakistani manufacturers. ${ }^{7}$ This will help the government identify the product categories for which tariffs should be reduced within each sector.

\footnotetext{
${ }^{6}$ As an example, high quality denim is already produced in Pakistan, this methodology recommends that intermediate input tariff should not be decreased on this quality of the intermediate input. Likewise, the methodology in this paper is extended to intermediate inputs used in these sectors at HS-10 digit.

${ }^{7}$ This is the average of the unit value of export and unit value of import for a specific product.
} 


\section{References}

Amiti, M., \& Konings, J. (2007). Trade liberalization, intermediate inputs, and productivity: Evidence from Indonesia. American Economic Review, 97(5), 1611-1638.

Arif, R., \& Jamil, N. (2018). Proposed methodology for strategic trade policy to achieve high value added exports: A case of Pakistan's textile sector (MPRA Paper No. 90380). Retrieved from https://mpra.ub.unimuenchen.de/90380/

Bas, M., \& Paunov, C. (2018). Input-quality upgrading from trade liberalization: Evidence on firm product growth and employment. Unpublished manuscript. Retrieved from https://www.researchgate.net/ publication/323760274_Input-quality_upgrading_from_trade_ liberalization_Evidence_on_firm_product_growth_and_employment

Bas, M., \& Strauss-Kahn, V. (2014). Does importing more inputs raise exports? Firm-level evidence from France. Review of World Economics, 150(2), 241-275.

Bigsten, A., Gebreeyesus, M., \& Söderbom, M. (2016). Tariffs and firm performance in Ethiopia. Journal of Development Studies, 52(7), 9861001.

Cruz, M., \& Bussolo, M. (2015). Does input tariff reduction impact firms' exports in the presence of import tariff exemption regimes? (Policy Research Working Paper No. 7231). Washington, DC: World Bank.

Ethier, W. (1982). National and international returns to scale in the modern theory of international trade. American Economic Review, 72(3), 389405.

Fan, H., Li, Y. A., \& Yeaple, S. (2015). Trade liberalization, quality, and export prices. Review of Economics and Statistics, 97(5), 1033-1051.

Feng, L., Li, Z., \& Swenson, D. L. (2016). The connection between imported intermediate inputs and exports: Evidence from Chinese firms. Journal of International Economics, 101, 86-101.

Goldberg, P. K., Khandewal, A., \& Pavcnik, N. (2013). Variety in and variety out: Imported input and product scope expansion in India. In J. Bhagwati \& A. Panagariya (Eds.), Reforms and economic transformation in India (pp. 168-199). New York: Oxford University Press. 
Goldberg, P., Khandelwal, A., Pavcnik, N., \& Topalova, P. (2010). Imported intermediate inputs and domestic product growth: Evidence from India. Quarterly Journal of Economics, 125(4), 1727-1767.

Gopinath, G., \& Neiman, B. (2014). Trade adjustment and productivity in large crises. American Economic Review, 104(3), 793-831.

Helpman, E., \& Krugman, P. (1985). Market structure and foreign trade. Cambridge, MA: MIT Press.

Kasahara, H., \& Rodrigue, J. (2008). Does the use of imported intermediates increase productivity? Plant-level evidence. Journal of Development Economics, 87(1), 106-118.

Kugler, M., \& Verhoogen, E. (2009). Plants and imported inputs: New facts and an interpretation. American Economic Review, 99(2), 501-507.

Rodrik, D. (1992). Closing the productivity gap: Does trade liberalization really help? In G. K. Helleiner (Ed.), Trade policy, industrialization and development: New perspectives (pp. 155-175). Oxford: Clarendon Press.

Topalova, P., \& Khandelwal, A. (2011). Trade liberalization and firm productivity: The case of India. Review of Economics and Statistics, 93(3), 995-1009. 
Appendix

Figure A1: Pakistan's trade deficit of goods and services in current US\$, 1967-2016

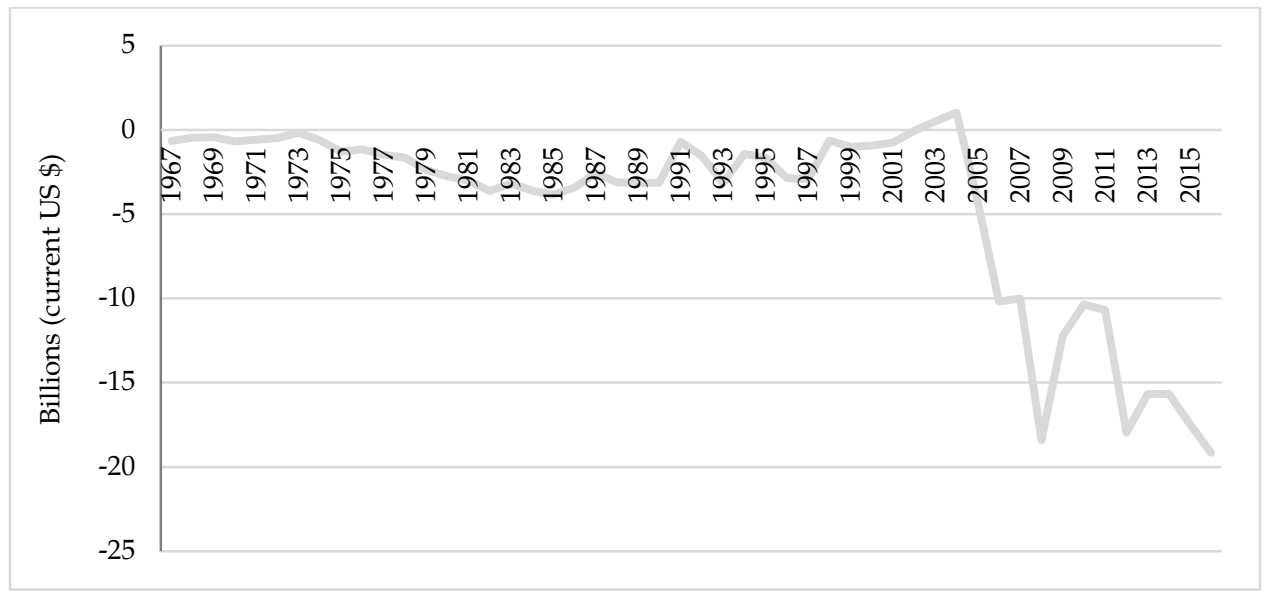

Source: The World Bank.

Figure A2: Average tariff rate applied to all imported goods by Pakistan, India, Sri Lanka, Turkey and Bangladesh, 2003-11

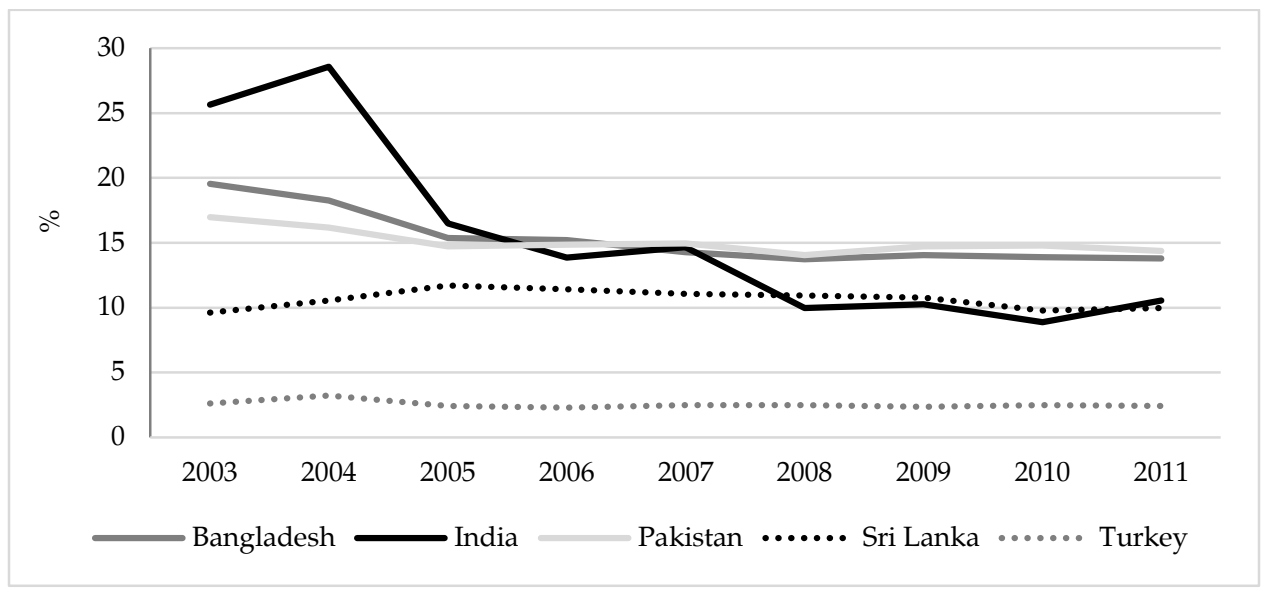

Source: World Integrated Trade Solution. 
Figure A3: Average tariff rate applied to imports of intermediate goods from China, 2003-11

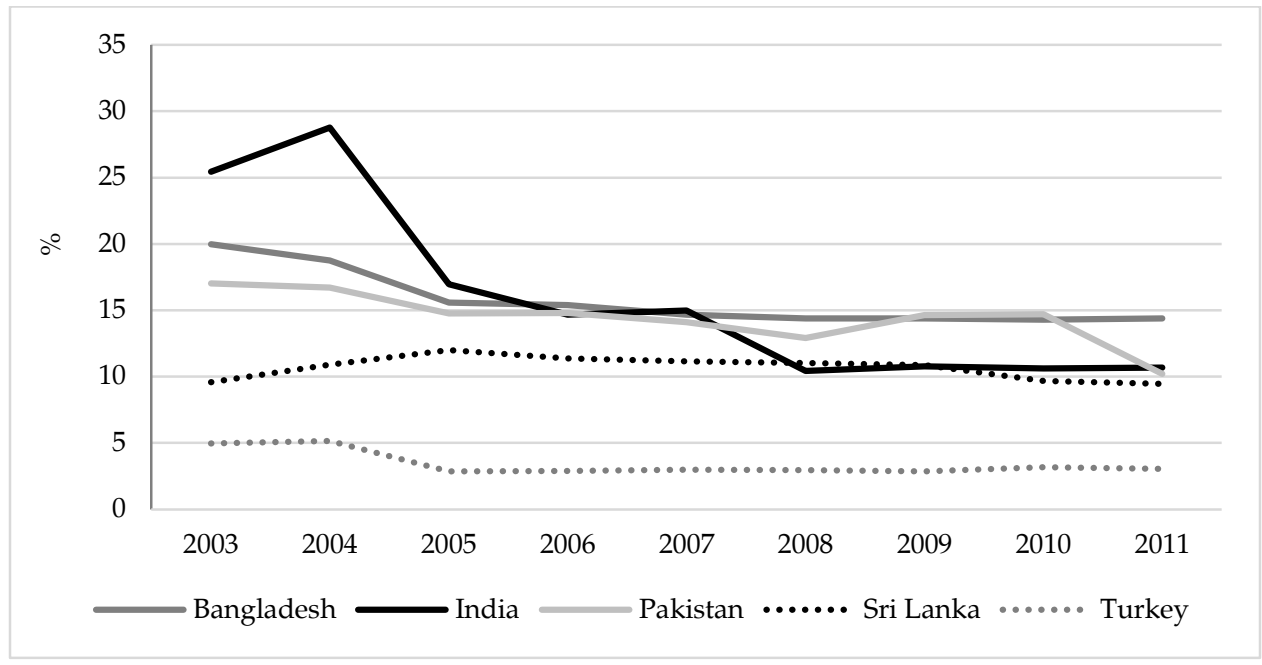

Source: World Integrated Trade Solution. 